\title{
Molecular Diversity of Azotobacter sp. Isolates from Rhizosphere of Tropical Tasar Silkworm Host Plants
}

\author{
Manjappa*, I.G. Prabhu, Niranjan Kumar and A.K. Sinha
}

Central Tasar Research and Training Institute, Ranchi, Jharkhand, India

*Corresponding author

\begin{tabular}{|c|c|}
\hline & B \\
\hline Keywor & \multirow{3}{*}{$\begin{array}{l}\text { Azotobacter is an aerobic, free living bacteria fixes atmospheric nitrogen in soil besides } \\
\text { producing plant growth promoting substance. Eight Azotobacter isolates were isolated and } \\
\text { purified from different tasar rearing regions of West Singhbhoom, Jharkhand on Jenson } \\
\text { media by using serial dilution technique. Molecular diversity among these isolates was } \\
\text { analysed using RAPD primers. Of the } 20 \text { decamer primers screened, } 10 \text { primers amplified } \\
\text { clear and distinguishable fragments and yielded a total of } 103 \text { fragments, of which } 101 \\
\text { fragments are polymorphic ( } 98 \% \text { ). Unweighted neighbour joining dendrogram based on } \\
\text { Dice indices divides eight Azotobacter isolates in two major clusters. Dissimilarity matrix } \\
\text { showed a maximum difference of } 76 \% \text { between the isolate from Hatghamaria (Azo 21-1) } \\
\text { and Talaburu (Azo 29-1) and minimum difference of } 39 \% \text { between the isolates derived } \\
\text { from the same region, Kharswan (Azo } 14 \text { and Azo 15-1). Thus RAPD marker analysis was } \\
\text { found to be easy and rapid in assessing diversity among Azotobacter isolates. }\end{array}$} \\
\hline Ar & \\
\hline $\begin{array}{l}\text { Accept } \\
20 \text { June } \\
\text { Availab } \\
10 \text { July }\end{array}$ & \\
\hline
\end{tabular}

\section{Introduction}

India is the only country producing all five known commercial silks viz., Mulberry, Tropical Tasar, Oak Tasar, Eri and Muga. India is producing 28,472 MTs of raw silk that includes 20,434 MTs of mulberry silk, 2,818 MTs of Tasar silk, 5,054 MTs of Eri silk and 166 MTs of Muga silk (CSB, 2015-2016). Among five types of silks tropical tasar silk is unique in its sheen, durability and thermal properties (Gangwar et al., 2007) and has been an integral part of traditional culture since centuries. In tropical tasar culture, silkworm cocoons are collected from forest plants (Shorea robusta or Terminalia tomentosa) or silkworm is reared on forest/systematic plantation (T. tomentosa and/or T. arjuna). As tasar culture is forest based ecofriendly cottage industry, it forms an integral part of tribal economy, employing 1.25 lakhs of tribal families residing in forest associated rural areas of Jharkhand, Bihar, Chhattisgarh, Orissa, Andhra Pradesh, Maharashtra, West Bengal and Uttar Pradesh (Reddy et al., 2015). In recent decades tasar culture is shifting from forest based cocoon collection (subsistence culture) to intensive silkworm rearing under systematic/natural plantation (commercial culture).To facilitate tribal tasar farmers, systematic plantations ( $T$. arjuna) have been raised in forest land, government waste land, 
marginal land and non-agricultural landsby various government projects viz., Cluster development and cluster promotion programmes (CDP, CPP), Mahila Krishi Shashktikaran Pariyojna (MKSP) and Swarnjayanti Gramin Swarojgar Yojna (SGSY) (Gargi et al., 2015). Hence the area under systematic plantation is being increased. Conversely, under commercial rearing, the quality of cocoon is being decreased as compared to forest based cocoons. Poor leaf quality under commercial rearing could be the major factor influencing cocoon quality, which is associated with decreasing soil nutrient contents through continuous silkworm rearing. Decreasing soil nutrient status is primary cause of poor leaf quality (Subbaswamy et al., 2004). To maintain soil nutrient status, external application of fertilizers/manure is not a feasible approach due to two reasons. First, tribal farmers are not affordable to manures/fertilizers due to their poor economic status and it increases input cost. Second, majority of tasar plantations are located in forest area, where application of chemical fertilizer is not advisable. Under this circumstance, application of biofertilizer is an ecofriendly, sustainable and feasible approach, which is affordable to farmers in low cost.

Among plant growth promoting rhizosphere microorganisms (PGPMs), Azotobacter is a free living bacteria known to fix atmospheric Nitrogen and produces plant growth promoting substances viz., hormones, vitamins and amino acids. Besides, they act as biocontrol agent against soil borne pathogens by secreting antifungal substances, hydrogen cyanide and siderophores (Gurikar et al., 2015). In the selection of bacterial inoculum to crop plants, indigenous isolates are more preferred as they can adapt to local ecosystem and more competitive than non-indigenous of inoculum (Bhattarai and Hess, 1993).Therefore the objectives of present study were to isolate Azotobacter strains from tasar host plant rhizosphere of different tasar rearing regions and to compare diversity among indigenous strains.

\section{Materials and Methods}

\section{Collection of soil samples}

For the isolation of Azotobacter bacterial isolates rhizosphere soil samples were collected from different tasar rearing regions of West Singhbhoom region of Jharkhand state (Table 1). Soil samples were collected from both forest as well as block plantations covering $T$. tomentosa and $T$. arjuna host plants. In each sampling location three rhizosphere soil samples were collected by following three-point sampling method (Malik et al., 1982) at soil surface layer, one feet depth and one meter apart from the trunk of host plant. Three rhizosphere soil samples were then mixed and stored immediately in polythene cover at $4^{\circ} \mathrm{C}$, which were later transported to lab. Soil samples were processed after removing debris and pebbles. The soil $\mathrm{pH}$ and electrical conductivity was also been recorded using $\mathrm{pH}$ meter and conductivity meter respectively.

\section{Isolation and purification of strains}

Azotobacter sp. strains were isolated from rhizosphere soil samples by serial dilution technique, where $100 \mu \mathrm{L}$ of $10^{-4}$ and $10^{-}$ ${ }^{5}$ inoculum was inoculated on Jenson agar (Jensen, 1951) (sucrose 20.0g, $\mathrm{K}_{2} \mathrm{HPO}_{4} 1.0 \mathrm{~g}$, $\mathrm{MgSO}_{4} .7 \mathrm{H}_{2} \mathrm{O} 0.5 \mathrm{~g}, \mathrm{NaCl} 0.5 \mathrm{~g}, \mathrm{FeSO}_{4} 0.1 \mathrm{~g}$, $\mathrm{Na}_{2} \mathrm{MoO}_{4} 0.005 \mathrm{~g}, \mathrm{CaCO}_{3} 2.0 \mathrm{~g}$, Agar $15.0 \mathrm{~g}$, distilled water $1 \mathrm{~L}$ ) by pour plate method. Petri dishes were then incubated at $30^{\circ} \mathrm{C}$ for $48 \mathrm{hr}$. Based on colony morphology different isolates were purified by streaking and single colonies were stored in slants for further use. Among several isolates, one isolate from each sampling location (8 isolates) was selected for molecular diversity. 


\section{Genomic DNA isolation}

For the genomic DNA extraction Eight Azotobacter bacterial isolates were inoculated in Luria broth and incubated overnight at $30^{\circ} \mathrm{C}$. About $2 \mathrm{ml}$ of liquid culture was centrifuged at $5000 \mathrm{rpm}$ for 10 minutes and supernatant was removed. To wash pellet,500 $\mu \mathrm{l}$ of Millipore water was added and centrifuged at 10,000 rpm for $10 \mathrm{~min}$, this step was repeated twice. Bacterial genomic DNA was isolated by using DNA isolation kit (Bioline, USA) as per the given protocol. The DNA was quantified on $0.8 \%$ Agarose gel using a known quantity of $\lambda$ DNA $(10 \mathrm{ng} / \mu \mathrm{l})$ as a standard before use in subsequent PCRs.

\section{PCR amplification of DNA using RAPD markers}

Eight isolates were screened for their diversity using RAPD markers. Initially 20 RAPD primers were screened to test the amplification, of which 10 (Table 2) were shown clear and distinguishable bands. PCR reactions were performed in a final volume of $25 \mu \mathrm{L}$ containing $30 \mathrm{ng}$ of template DNA, 200 $\mu \mathrm{M}$ dNTP, $1.5 \mathrm{mM} \mathrm{MgCl}_{2}, 2 \mu \mathrm{L}$ of $10 \mathrm{X}$ reaction buffer $(50 \mathrm{mM} \mathrm{KCl}, 10 \mathrm{mM}$ Tris- $\mathrm{HCl}$ $\mathrm{pH} 9.0,0.05 \%(\mathrm{v} / \mathrm{v}) \mathrm{NP} 40$ and $0.05 \%(\mathrm{v} / \mathrm{v})$ Triton X-100), $2.5 \mu \mathrm{L}$ of 5 pmole primer and 1 unit of Taq DNA polymerase (Sigma Aldrich Chemicals, Bangalore, India). Polymerase chain reactions (PCR) were performed in Techne TC-512 thermocycler (Techne, TC512, USA) with the program consisting of initial denaturation at $94^{\circ} \mathrm{C}$ for 5 min followed by 40 cycles each consisting of denaturation at $94^{\circ} \mathrm{C}$ for $1 \mathrm{~min}$, primer annealing at $36^{\circ} \mathrm{C}$ for $1 \mathrm{~min}$, primer extension at $72^{\circ} \mathrm{C}$ for $2 \mathrm{~min}$ and a final extension of $72^{\circ} \mathrm{C}$ for $10 \mathrm{~min}$. The amplified PCR products were size fractioned by electrophoresis on $1.5 \%$ Agarose gel (UAB, Affymetrix, Inc.) in $1 x$ in $1 \times$ Tris borate EDTA buffer and gels were stained with Ethidium Bromide $(0.5 \mu \mathrm{g} / \mathrm{ml})$.A $1 \mathrm{~kb}$ standard molecular marker (MassRuler DNA
Ladder Mix, Thermo Fisher Scientific, USA) was used in every electrophoretic run and gel was visualized in UV-Trans illuminator (genetix, Biotech Asia Pvt. Ltd.).

\section{Molecular data analysis}

Each RAPD markers across eight Azotobacter isolates were scored by comparing standard size marker run along with the gel and scoring was recorded in binary system (' 1 ' for presence and ' 0 ' for absence). Binary data was used in the computation of Dice indices (Perrier et al., 2003), which was calculated using following formula.

$$
d_{i j}=\frac{b+c}{2 a+(b+c)}
$$

Notations:

dij: dissimilarity between units $\mathrm{i}$ and $\mathrm{j}$ $x i, x j$ : variable values for units $i$ and $j$

a: number of variables where $x i=$ presence and $\mathrm{xj}=$ presence

$\mathrm{b}$ : number of variables where $\mathrm{xi}=$ presence and $x j=$ absence

c: number of variables where $x i=$ absence and $\mathrm{xj}=$ presence

Dissimilarity matrix was developed by using Dice indices with a bootstrap value of 10,000.Dissimilarity matrix was then used to construct a dendrogram using Unweighted Neighbour Joining method of clustering using DarWin v.6 software (Perrier et al., 2003). To evaluate the robustness of dendrogram and its confidence limits, bootstrapping with 10000 replication was performed.

\section{Results and Discussion}

In the preparation of biofertilizer for any crop, indigenous bacterial isolates are preferred due to better adaptation to their crop ecosystem and good agronomic performance. Hence, in present study Azotobacter isolates were isolated from rhizosphere soil samples of tasar 
host plants ( $T$. arjuna and $T$. tomentosa). The rhizosphere soil samples were collected from different tasar rearing areas of West Singhbhoom, Jharkhand state. About 18 Azatobacter isolates were isolated from eight locations. One isolate from each location was analysed to understand diversity among the isolates.

Initially twenty RAPD primers of arbitrary sequences were screened on two isolates DNA, out of which 10 primers were selected based on their distinct and clear amplification profiles (Table 2). Polymorphic gel profiles of RAPD primer PWD6 is shown in figure 1. Screening of primer is essential to save time and cost, and to reject primers which are not informative for the analysis (Prakash et al. 2002.). A total of 103 clear and readable RAPD fragments were produced from 10 RAPD primers (Table 2), of which 101 (98.05\%) fragments were polymorphic. The number of RAPD fragments per primer ranged from 5 (OPAJ4 and OPAJ07) to 21 (OPA21) with an average of 10.3 fragments per primer.

Table.1 Details of Azotobacter isolates used in the molecular diversity

\begin{tabular}{|c|l|l|l|}
\hline Isolate Code & Place of collection & Host plant & Plantation type \\
\hline Azo 14-1 & Karsawan(Farmers field), & Arjun & Block plantation \\
\hline Azo 15 & Karsawan (Farmers field) & Asan & Block plantation \\
\hline Azo 21-1 & REC, Hatghamaria & Arjun & Block plantation \\
\hline Azo 23 & REC, Hatghamaria & Asan & Forest \\
\hline Azo 26-1 & PPC, Debrasai & Arjun & Forest \\
\hline Azo 26-2 & PPC, Debrasai & Arjun & Forest \\
\hline Azo 29-1 & Thalaburu (Farmers field) & Arjun & Block plantation \\
\hline Azo 31 & CTR\&TI, Ranchi & Arjun & Block plantation \\
\hline & & & \\
\hline
\end{tabular}

Table.2 The sequence and level of polymorphism of selected polymorphic primers in Azotobacter

\begin{tabular}{|r|l|l|c|c|c|}
\hline $\begin{array}{c}\text { Sl. } \\
\text { No. }\end{array}$ & Primers & Sequence (5'-3') & $\begin{array}{c}\text { No. of amplified } \\
\text { fragments }\end{array}$ & $\begin{array}{c}\text { No. of monomorphic } \\
\text { bands }\end{array}$ & $\begin{array}{c}\text { No. of polymorphic } \\
\text { bands }\end{array}$ \\
\hline $\mathbf{1}$ & OPW 6 & AGGCCCGATG & 14 & 0 & 14 \\
\hline $\mathbf{2}$ & OPW 9 & GTGACCGAGT & 9 & 0 & 9 \\
\hline $\mathbf{3}$ & OPW 16 & CAGCCTACCA & 15 & 0 & 15 \\
\hline $\mathbf{4}$ & OPK 10 & GTGCAACGTG & 7 & 0 & 7 \\
\hline $\mathbf{5}$ & OPKO4 & CCGCCCAAAC & 10 & 0 & 10 \\
\hline $\mathbf{6}$ & OPA 21 & GAGGACTAGG & 21 & 1 & 20 \\
\hline $\mathbf{7}$ & OPA 11 & CAATCGCCGT & 6 & 1 & 5 \\
\hline $\mathbf{8}$ & OPAJ 4 & GAATGCGACA & 5 & 0 & 5 \\
\hline $\mathbf{9}$ & OPAJ 07 & CCCTCCCTAA & 5 & 0 & 11 \\
\hline $\mathbf{1 0}$ & OPAJ 15 & GAATCCGGCA & 11 & 0 & 101 \\
\hline & Total & & 103 & 2 & 5 \\
\hline
\end{tabular}


Table.3 Genetic dissimilarity matrix of 8 Azotobacter isolates based on polymorphism of 10 RAPD markers

\begin{tabular}{|c|c|c|c|c|c|c|c|c|}
\hline $\mathbf{1 4 - 1}$ & $\mathbf{0 . 0 0 0}$ & & & & & & & \\
\hline $\mathbf{1 5}$ & 0.394 & 0.000 & & & & & & \\
\hline $\mathbf{2 1 - 1}$ & 0.538 & 0.647 & 0.000 & & & & & \\
\hline $\mathbf{2 3}$ & 0.500 & 0.528 & 0.610 & 0.000 & & & & \\
\hline $\mathbf{2 6 - 1}$ & 0.643 & 0.521 & 0.561 & 0.619 & 0.000 & & & \\
\hline $\mathbf{2 6 - 2}$ & 0.686 & 0.508 & 0.500 & 0.544 & 0.571 & 0.000 & & \\
\hline $\mathbf{2 9 - 1}$ & 0.688 & 0.590 & 0.760 & 0.718 & 0.652 & 0.647 & 0.000 & \\
\hline $\mathbf{3 1}$ & 0.507 & 0.518 & 0.708 & 0.627 & 0.541 & 0.618 & 0.550 & 0.000 \\
\hline
\end{tabular}

Figure.1 RAPD profiles of Eight Azotobacter isolates for OPW6 primer. Lane 1-8 contains amplification profiles of eight isolates. Lane M: 1kbstandard DNA marker

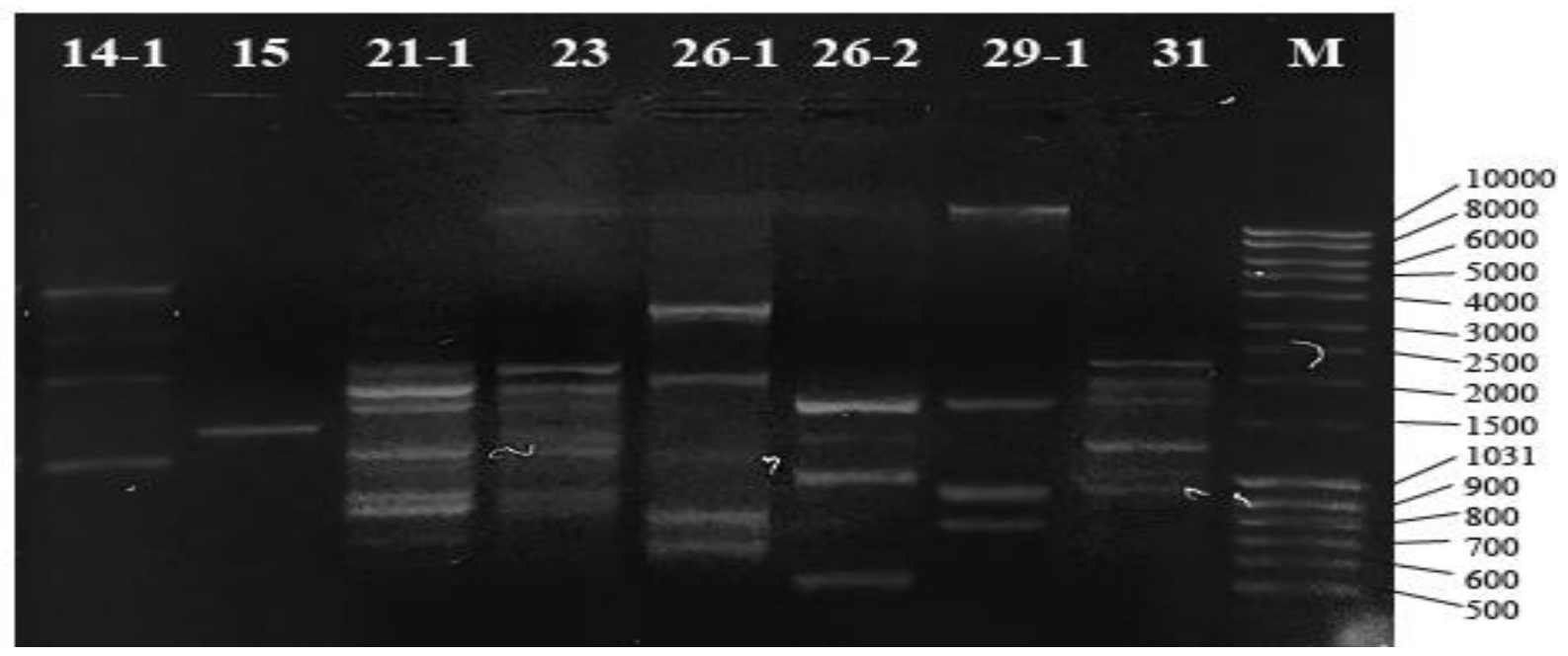

Figure.2 Cluster analysis. Dendrogram showing RAPD-marker-based genetic relationships among 8 Azatobacter isolates and grouping them into two clusters ' $A$ ' and 'B' with five and three isolates, respectively

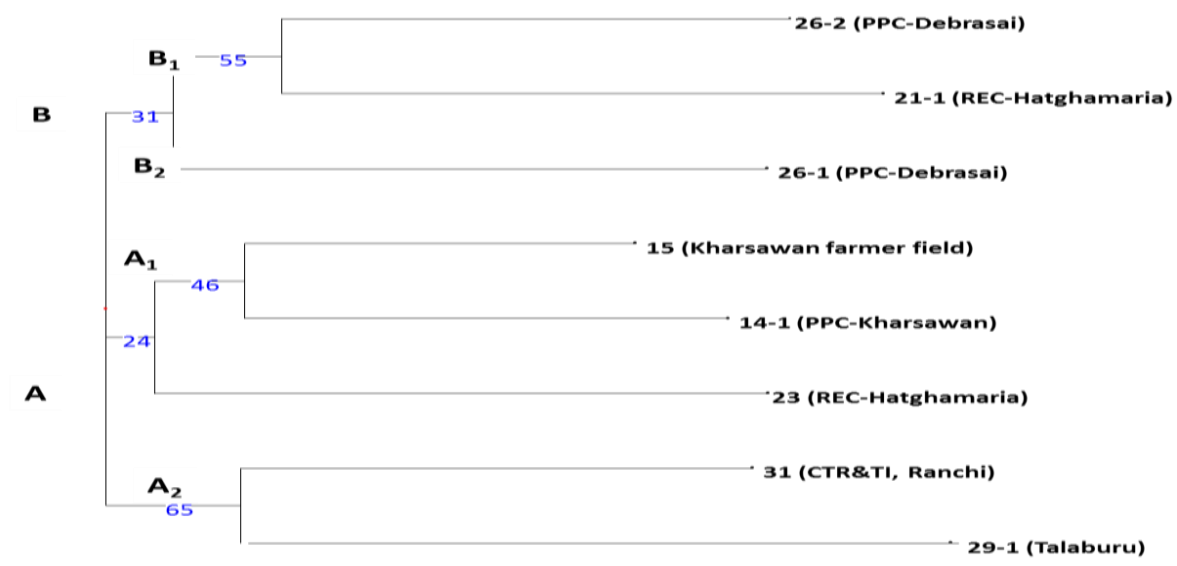


Similarly Anatha Naik et al., (2008) also obtained high polymorphic RAPD fragments (84.4\%) among ten Azotobacter crococcum isolates isolated from different agro-climatic zones of Karnataka. The polymorphic RAPD profiles of eight Azotobacter isolates were used in computation of dissimilar matrix using Dice indices (Perrier et al., 2003). The dissimilarity among eight Azotobacter isolates, as revealed from dissimilarity matrix varies from 0.394 to 0.760 (Table 3). Isolates from Talaburu (Azo 29-1) and REC, Hatghamaria (Azo 21-1) were found to be more diverse, whereas isolates from PPC Kharswan (Azo 14) and Farmer field, Kharswan (Azo 15-1) are less diverse (Table 3).

Unweighted neighbour joining dendrogram constructed from dissimilarity matrix has clustered eight Azotobacter isolates into two major clusters i.e. cluster $\mathrm{A}$ and cluster $\mathrm{B}$ and four sub clusters i.e. $A_{1}, A_{2}, A_{3}$ and $A_{4}$ (Fig. 2 ). It is noticed that, isolates derived from closer geographical regions have clustered together in cluster B(Azo 21-1, Azo 26-1 and Azo 26-2) and in sub cluster $A_{1}$ (Azo 14-1 and Azo 15).

All the Azotobacter isolates in the present study were collected from different geographical locations with diverse agroclimatic conditions and hence showed relatively high polymorphism as revealed by dissimilarity matrix and dendrogram. Hence, RAPD-PCR based DNA fingerprinting of the genomic DNA with arbitrary primers is a rapid and sensitive method for the detection of genetic variation among different isolates of Azotobacter.

\section{Acknowledgement}

The financial support (Project No. PPA-4717) of the Central Silk Board (CSB), Ministry of Textiles, Govt. of India is gratefully acknowledged. The Silkworm breeding and Genetics and Silkworm pathology departments are acknowledged for laboratory support.

\section{References}

Anantha Naik, T.,N. Earanna,P. Narayanaswamy and Luke, S. 2008. Molecular characterization of Azotobacter chroococcum strains isolated from different agro-climatic zones of Karnataka, India. Dynamic Soil, Dynamic Plant. 2(2): 73-76.

Bhattarai, T. and Hess D., 1993. Yield responses of Nepalese spring wheat $(T$. aestivum L.) cultivars to inoculation with Azospirillum spp. of Nepalese origin. Plant and Soil. 151: 67-76.

CSB (Central Silk Board), 2016. Note on the performance of Indian silk industry \& functioning of central silk board.

Gangwar, S. K., R. Kumar and Srivastava, S. K., 2007. Tasar culture- Principles and practices: Tasar silkworm biology, Vol-II. Central Tasar Research and Training Institute, Central Silk Board, Ministry of Textiles, Piska Nagri, Ranchi.

Gargi, R.Kumar, M.Deka, H.Yadav and Alok Sahay, 2015. Crossability studies in Terminaliaarjuna and T. tomemtosa. International Journal of Applied Biology and Pharmaceutical Technology.6(3): 211-216.

Gurikar C., M.K. Naik and Sreenivasa, M.Y., 2016. Azotobacter: PGPR Activities with special reference to effect of pesticides and biodegradation. D.P. Singh et al., (eds.), Microbial inoculants in sustainable agricultural productivity. 229-244. doi: 10.1007/978-81-322-2647-5_13

Jensen, V., 1951. Notes on the biology of Azotobacter. Proc. Soc. Appl. 
Bacteriol., 74: 89-93.

Malik, K.A., Zafar, Y., Hussain A., et al., 1982. Associative dinitrogen fixation in Diplachne fusca (Kallar grass). Biological nitrogen fixation technology for tropical agriculture. 503-507.

Perrier, X., A. Flori,F. Bonnot, 2003. Data analysis methods. In: Hamon, P., M.Seguin, X. Perrier, Glaszmann, J. C. Ed., Genetic diversity of cultivated tropical plants. Enfield, Science Publishers. Montpellier. 43 - 76.

Reddy, P.M. Muniswamy, V.P. Gupta and
Lokesh, G., 2015. Impact of trainers training programmes of integrated skill development scheme (ISDS) in tasar technologies. Global Journal of BioScience and Biotechnology. 4(1): 17-20.

Subbaswamy, M.R., N.R.Singhvi, B. V. Naidu, M. M. Reddy, H. Jayaram, and Suryanarayan, N. 2004. Effect of source of nitrogen on phosphorus uptake and arginine content in mulberry. Indian J. Sericulture. 40: $182-184$.

\section{How to cite this article:}

Manjappa, I.G. Prabhu, Niranjan Kumar and Sinha, A.K. 2018. Molecular Diversity of Azotobacter sp. Isolates from Rhizosphere of Tropical Tasar Silkworm Host Plants. Int.J.Curr.Microbiol.App.Sci. 7(07): 2800-2806. doi: https://doi.org/10.20546/ijcmas.2018.707.327 